\title{
DISCRIMINATION AGAINST WOMEN AND THE HUMAN RIGHTS OF WOMEN ${ }^{*}$
}

\begin{abstract}
This paper investigates the concept of the human rights of women and its connection with the phenomenon and the instances of discrimination against women. Discrimination against women, its social visibility and the fight against it, within the idea of the rights and the equality of women, are a source of many theoretical debates. Academic discussions and a powerful influence of the women's movement have brought about the establishment and the exercise of the human rights of women at different levels of the public and the private spheres of society, as a substantial part of the universal regime of human rights.
\end{abstract}

Key words: gender, discrimination against women, women's rights, human rights.

\section{Introductory remarks}

On a map of social processes and relations, we can clearly distinguish those social spaces where discrimination against women occurs, where women are regarded as a social group which has different social positions in many aspects of life. When Richard Rorty speaks about the culture of human rights, he states some general attitudes towards women as paradigmatic examples of excluding certain groups of people from the community: "Men tend to say that women always remain children: that is why it is meaningless to spend money on their education, and their access to the government should be prevented. When it comes to women, there are simpler ways to exclude them from the real human *natalija@prafak.ni.ac.rs

** This paper, in a somewhat altered form, has also been published in: Konstantinović, Vilić, S. Kostić, M. ed. Pravna klinika za zaštitu prava žena. Priručnik za rad studentkinja/studenata. (2011). The Faculty of Law of the University of Niš and the Women's Research Centre for Education and Communication in Niš. 
community: for example, by using the word "man" as a synonym for a "human being". As the feminists have pointed out, such usage reinforces the gratitude of an average man for the fact that he was not born a woman, as well as his fear of the worst degradation - feminisation" (Rorty, 1995-1996: 45). The historical nature of women's rights and the status of women in the modern society show the way in which the context of the rights of women is a determined phenomenon of discrimination against women. Therefore, the discussion about the conceptualisation of the notion of women's rights should be focused on the very notion of discrimination against women and the ways in which it manifests, as well as, on the mechanisms of maintaining the system of discrimination against women. The recognition of the entire context of discrimination against women also opens up an essential question about the overcoming of discrimination as an important political question.

Studies and analyses of stratification have shown, according to A. Giddens, that, for many years, no "attention has been paid to the question of gender - the studies have been written as if women did not exist, or as if they were not important or interesting when it comes to the analyses of divisions of power, wealth and prestige. However, gender is, by itself, one of the most illustrative examples of stratification. There is no society in which men, at least in some aspects of social life, do not have more wealth, a higher status and a larger influence than women" (Giddens, 1989: 239). That is, among other things, a social fact which has made the analysis of discrimination against women the vertical of socio-feminist debates within the research of the position of women (See in detail: Walsh, 1997).

\section{Discrimination and gender}

Discrimination against women is defined as the "unfavourable treatment of women in the public sphere which results in their unfavourable position within the distribution of all important social resources (material wealth, power and status)" (Blagojević, 2000: 478), and it is based on the "logic" of the patriarchal/ traditional system of social power. Within the researches of this social phenomenon, M. Blagojević points out that discrimination and misogyny (Blagojević, 2002: 23-24) ${ }^{1}$, as well as the exploitation of women and the violence against women, are a part of the problem of the patriarchal/traditional social framework.

1 Misogyny is hate towards women. "In a wider sense, it refers to unreasonable hate and/ or fear, which are usually accompanied by a feeling of hostility and repulsion. Misogyny is present in institutional and everyday activities, in public discourses, and in private intimate relations. Its characteristics are that it is almost omnipresent (ubiquitous), institutionalised, most often ritualised, and, at the same time, ideologised, serving as an excuse for the exclusion, hierarchisation and exploitation of women. In that sense, misogyny is, at the same time, an ideology, a practice, a discourse and a cultural institution, but also, a relation between 
Namely, the relations between men and women, and their real position within society, as well as the degree of expression of discrimination against women, are significantly determined by the attitudes and values about men and women, which are shared by a wider social community. Within the researches and the literature regarding the question of women, the social phenomenon known as the "gender paradox" shows that "when traits or behaviours which are connected to a woman are evaluated as negative or less valuable - then, the gender is relevant, that is, when a trait or a behaviour which is connected to a woman is evaluated as positive or valuable - then, the gender is irrelevant" (Rosener, 1997: 296). This gender-based "value consensus" in a certain society is a collection of many factors which determine the degree of egalitarianism of that society. Those are the societies which are defined, to a certain extent, by the traditional culture, where the economic development is on a lower stage, where the church expounds public views, where there is a lack of civic tradition and the tradition of political protest and where the feminist movement does not have tradition and is not accepted by the wider public.

A great number of researches, concerning the discrimination of women, which have been conducted by M. Blagojević, show us the fact, as she states, that not only discrimination can be empirically proved, but that we can also empirically determine the existence of a systematic inhibition which affects women as members of a marginal group, and which is important for its explanation. ${ }^{2}$ The systematic inhibition is a social construct and it is understood as a "collection of social mechanisms which affect the quantitative reduction and the qualitative degradation of the activities of women and their entire social position. The systematic inhibition, which has to be overcome by women in their process of climbing up the ladder of social hierarchy, is manifested in five areas: 1. the area of work; 2. the area of socialisation and education; 3 . the area of occupation; 4. the area of creativity, and 5. the area of the family" (Blagojević, 1991: 483-484). In order to overcome the limitations imposed by the system in these specified areas, women are, therefore, forced to have both a greater number of and more

people. In its core, it is essentialist, because it is applied to "all women", and femininity is biologically defined" (Blagojević, 2002: 23-24).

General prevalence and social acceptance of misogyny go hand in hand with the social domination of men and the inequality of social opportunities for men and women.

2 Women, as a social group, are characterised by their belonging to a marginal group. That shows their less favourable position in relation to men; therefore, from that position, women are in some way denied the access to all fundamental social resources (cultural, economic and political). As a "marginalised majority" they are "granted" the position of marginalised people, which is obtained by women as well as other marginalised groups (children, old people, invalids, Roma, black people and others) because of their other, different from the dominant group and the dominant culture, biological and/or cultural habitus. 
emphasised promotional mechanisms ${ }^{3}$ than men, who are, in a social sense, the dominant group.

Namely, women are prevented to have equal participation as men in the labour market, that is, in the distribution of occupations and positions which secure wealth and reputation, and where a significantly greater concentration of social power can be found. Researches show that discrimination against and segregation of women in the workplace have a direct influence on the earnings of women and on the amount of power they exercise. This is manifested in two ways, and those are: a) horizontal discrimination - the segregation of women within the private sphere is based on the construction of social roles and stereotypes which structure the gender-based division of labour. In this way, occupations are separated based on the gender which traditionally plays such roles: for instance, teaching, nursing, housekeeping - for women; mechanics, medicine, engineering - for men; b) vertical discrimination - the respect of men and the placement of women into the position of subordination and submission, as well as not valuing their prescribed duties (Facio, Sandova, Morgan, 2005: 115).

The problem of discrimination also becomes socially visible when the chances for the social success of women (and their representation rate) start to diminish as we go towards the positions which are fewer and more sought after. Bourdieu states that the rate of current and potential feminisation is undoubtedly the best indicator of the positions and values of different occupations (Bourdieu, 2001: 126). The cultural gender-based pattern presupposes that the positions of power and social prestige are reserved for men. Of course, there are exceptions, and some women also occupy prestigious positions, but gender balance is a sporadic occurrence, even at the level of the European area. Women make up more than half of the population and electorate in the European Union (EU), yet they continue to be underrepresented in all economic and political decision-making bodies at all levels. The average representation of women in national parliaments is $24 \%$ and in national governments $23 \%$. The number of women presidents of Europe's largest companies has fallen from 4\% to 3\% since 2004. For the European Women's Lobby (EWL) and its members, this underrepresentation of women constitutes a serious democratic deficit, which undermines the legitimacy of the contemporary democratic ideal (European Women's Lobby, Report. 2013).

3 Subjective (qualification, competitive personality traits and the rest) and objective (family "background", support from others, origin and the rest) elements of the promotion of women always have to be more intensive and more persuasive than with men, when they are both in the "race" for the same position on a hierarchical ladder. Marina Blagojević states that several researches of hers have confirmed the connection between the sex/gender and the strength of the promotional mechanisms, that is, more precisely, between the sex/gender and the strength of discrimination (Blagojević, 1991: 484). 
Therefore, among other things, the dogma about the inferiority of women selfrenews and becomes grounded in the circumstances when the social control of discrimination against women enters the system of institutional application and protection of women's rights. Discrimination, as a structural concept, refers to systematic denials to certain social groups. Its causes lie in customs and standards which are not questioned, in prejudices which are supported by the institutionalised rules and in all other consequences of obeying such rules. In other words, "discriminatory discourse is a part of our many everyday experiences" (Young, 1999: 40).

Therefore, in a structural sense, discrimination refers to deep injustice which is suffered by some groups, often as a consequence of unconscious stereotypes, prejudices and reactions in ordinary communication, media and cultural stereotypes and market-based mechanisms, that is, everything that is part of the process of everyday life. ${ }^{4}$ We cannot eliminate structural discrimination just by creating new laws or just by changing the political context; the essence is in the multidimensional reproduction of structural discrimination in the most important economic, political and cultural institutions. "The opposition to structural discrimination demands a process of questioning basic cultural values and fundamental principles of social organisation" (Pincus, 2000: 31-35). On a historical level, the areas of social life within which it is possible to indicate discrimination against women have had, it would appear, completely different dimensions regarding its content, intensity and social visibility. Based on the wider structures of inequality, it could be said that discrimination against women is exercised at different places and under different circumstances within society, which clearly indicates that there are double standards regarding the rights of people - men and women.

It is a social fact that, in the labour market, women are "always paid less than men, even when everything else is the same, that they obtain less significant positions even though they have the same academic degrees, and, particularly, that they are proportionally more affected by unemployment and more often placed in part-time positions - which, among other things, consequentially leads to an almost certain exclusion from the power games and career perspectives"

4 I. M. Young, in her experimental essay "Five Faces of Oppression," emphasised the existence of: a) exploitation, b) marginalisation, c) powerlessness, d) cultural imperialism and e) violence, as five clear forms of discrimination of social groups and individuals within them. In this way, racism, sexism, ageism, and/or homophobia, with their clear dynamics, affect social groups such as women, old people, racial and ethnic groups, religious groups, handicapped, groups of different sexual orientation, and other. According to her researches, women as a group are exposed to gender-based exploitation, powerlessness, cultural imperialism and violence (Young, 1990: 40). 
(Bourdieu, 2001: 127). The phenomenon named "glass ceiling"5 is only a finite sum of economic and social inequalities of women. This solid and invisible barrier is defined by Laurie Morgan as those cases in which "women start their career from the same entry position as men, but, in time, they either have a slower progress in comparison to men, or they continue to progress at the same rate until, at some moment, their progress is stopped « (Morgan, 1998: 126). In fact, even though they make up $40 \%$ of the global labour force, women occupy just around $20 \%$ of management positions, and, as the hierarchical level of positions increases, this percentage decreases to $1 \%$ for the top management positions. In essence, discrimination is marked by the existence of two poles where it is clearly shown that the first refers to politics, which is characterised by the partial absence of women and that the other - the family is characterised by the pronounced presence of women. A necessary consequence of this absence/ presence of women is the fact that the area of politics is most often articulated as the "male sphere", while the area of the family is unambiguously represented as the "female sphere". "There is no doubt that these are unique correlates, that is, that the presence of women within one area increases their absence in the other, and vice versa" (Blagojević, 1991: 492). The permeability of the system at the higher levels of social hierarchy is extremely limited for women, and this is particularly visible in those areas which hold the centres of power - in politics.

Pierre Bourdieu states that the structural relations of the gender-based government and the social correlation between them become visible, and that "women who have obtained very high positions (personnel, head of a ministry, etc.) have to "pay", so to speak, for that professional success with their lower 'success' within the family relations (by divorce, late marriage, celibacy, difficulties or failures of their children, etc.) and within the market of symbolic goods, or on the contrary, that success within the household is often partial or complete compensation for giving up on the professional success (especially through the acceptance of 'advantages' which are so easily ascribed to women only because they place them outside the 'rat race': for the half or 'four fifths' of their working hours)" (Bourdieu, 2001: 146).

5 The term "glass ceiling" has been widely used in literature since 1987, and its first usage was in 1970 in the USA. It identifies those occurrences which are characterised by the impossibility of women to make progress to the highest leading positions within the business hierarchy. The metaphor "glass walls" describes the occupational separation of women, which serves as a barrier and as a means to concentrate women within a certain type of occupation or activity, or to limit women to a certain occupation or activity. Significant empirical research of these phenomena in the field of public policies and the representation of women can be found in: Reid, Kerr, Miller, 2003: 23. The same phenomenon is discussed by Pierre Bourdieu in the previously mentioned book "Masculine Domination". 


\section{Gender, discrimination and the law}

It is certain that there is no society which treats women as good as men. The sociability of discrimination against women (Badinter, 1986: 207) indicates the systematic deprivation of women in public life, as well as the transfer of discrimination onto the structural and institutional levels of society. As we have already mentioned, the matrix of discrimination against women is the constant reproduction of discrimination in the fundamental cultural, economic and political institutions of a society. Discrimination is, therefore, an essential characteristic of the social position of a woman, whether observed on an individual or on a group level (Blagojević, 1991: 489). In fact, it is wrong to expect that, nowadays, we can mark and clearly recognise discrimination. "It is not one-dimensional, simple, and easily noticeable. On the contrary, the mechanisms, by which it operates, are more and more subtle" (Blagojević, 1991: 493).

Men and women consummate and exercise their rights in different and unequal ways, which also indicates their different social position, which is caused by the presence of discrimination - which is their coexisting, exemplary characteristic. When the question of gender became the focus of legal researches, through the analysis of the discourse of the human rights of women, it became clear that it is important to explain the problem which existed in the exercise of human rights of a group of people (the social group of men and the social group of women), connected by the same status. ${ }^{6}$ The discussion about the concept of the human rights of women, its origin and the reasons of its existence, should, perhaps, start from a known social fact that a woman has always been "only a mediator of the law, and not its beneficiary" (Beauvoir, 1982: 101). What does this social fact state, and what meaning does it have for the explanation of the creation of "women's rights"? How is this process of "obtaining" women's rights described and defined in the history and theory of human rights, and what are the social consequences of this process for the overall emancipation of people? Have the

6 In her analysis of the concept of a social group, Iris Young states that discrimination refers to a structural phenomenon which makes a social group weak and passive. Namely, in the very society, people are distinguished according to social groups such as men and women, age groups, racial and ethnic groups, religious groups, etc. However, "social groups of this kind are not only a simple collection of people; they are based on the intertwined identities of the people which they describe and which belong to them. They are a special kind of collectivity, with specific reactions which are based on the way they understand themselves and the way others understand them. A social group is made of individuals who are different from at least another social group in their cultural standards and lifestyles. The members of the group have special affinity towards each other due to similar experiences or lifestyles, which makes them more connected among themselves than with those who do not identify themselves with the group. Groups are an expression of social relations; a group exists only in relation to at least another group" (Young, 2002: 41). 
reasons of social and/or theoretical provenance been the cause of "conflicts" and misunderstandings between the theory of human rights and the concept of the human rights of women? Being that the analysis of the discourse of women's rights is in focus, we must not, after all, lose sight of the fact that the theory of law "is not and cannot be only a question of conceptualisation. Concepts do not exist in a timeless void, but they are an integral part of social life, and they cannot be treated as abstractions separated from the concrete forms of social relations" (Pateman, 1998: 104).

Human rights are established as the rights which are connected with the very conditionality of human beings (Levinas, 1995-1996: 30) and their right to freedom. People as individuals can demand, and they do demand, those rights on the basis of their existence as human beings, and the community is the one which makes legal guarantees in their behalf, due to ethical reasons. The elevation of "those rights to the level of fundamental principles of legislature and social order" (Levinas, 1995-1996: 30) represents, in a civilisational sense, the key moment in the history of the ideas of the Western cultural circle, and, also, one (of several) universally acknowledged moral vision of the humanity (Bunch, 1995-1996: 175). Therefore, human rights do not originate from the positive legal order of the state, but they belong to the moral structure of humans and to individuals as autonomous, free, equal and rational human beings. According to Richard Rorty, "the phenomenon of human rights is 'a worldwide fact,' and the general consent on the idea of human rights and its expansion calls for a new age, 'the age of rights', in which, as it seems, human rights have an opportunity to become universal, to become 'the general law of the people' (Rorty, 1995-1996: 46).

In its study of human rights, the theory of sociology ${ }^{7}$ is analytically directed towards the connections between an individual and the society, with the idea to explain the way in which human rights represent an individual and collective desire for human freedom. In the historical and political sense, the freedom and the equality of citizens are the essence of human rights, and, due to this fact,

7 Among other things, due to the manner and the consequences of the implementation of human rights and the human rights of women into our cultural context, it is useful to see the difference which exists between sociology and the mainstream within the study of human rights. This difference is, in fact, a product of tension which exists within philosophical debates around the ideas of universalism and relativism. Of course, the outcome of and the solution to the relativist-universalist debate will not be "useful" if it remains on the level of abstract considerations. It has to go towards a renewed understanding of culture as a process where attention is focused onto empirical specifics - in what way human rights and the local culture can dialectically affect each other, and how their specific position can produce new hybrid and accidental cultural consequences. (See the section on human rights in: Turner, 2006: 521.) 
at a certain historical and social moment, the accent have had to be put on the theoretical and institutional development of the concept of the human rights of women. The most remarkable achievement of the 1990s was, perhaps, the introduction of the question of sexual and reproductive health and right, violence against women, and unequal balance of power in gender-based relations, into the centre of global and national debates about human rights and human development (Gender Equality - Striving for Justice in an Unequal World, 2005: 1).

\section{Gender perspective: the human rights of women}

Within the question of whether the state is responsible for providing women with the freedom to exercise human rights (civic, political, economic, social and cultural rights), there has been a "hidden" seed of the debate, which has grown within the circles of the theorists of law who have insisted on the fact that there is no legal space for special rights of women beyond the concept of human rights which are universally projected. In a social sense, regardless of the theoretical debates and disputes, the insistence on the protection of women's rights has proved itself as inevitability and as a reaction to the systematic and historical nature of inequality between men and women. Most feminist female theorists emphasise two remarks which refer to the notion of human rights: the abstract character of the very notion of right, and the individualism upon which this notion is grounded. Therefore, if we would review the feminist criticism of human rights, we could state that human rights are actually the rights of men, and the state is using them as the means of controlling sexuality (Salecl, 1996: 17).

However, perhaps we could ask the question in this way: what kind of concept of universality is offered "within the society where certain groups are privileged, while others are subordinated, where it is insisted upon the fact that, as citizens, people have to replace their own inclinations and experiences with general attitudes - this only helps the further establishment of privileges, because, in this way, the attitudes and interests of the privileged will become dominant in such a unified public sphere, by marginalising and silencing the attitudes and interests of other groups" (Young, 2004: 419). Or, if going further - why are women "defined as subjects outside social relations, instead of considering in what way the women as women are constituted, precisely through structures (for example, legal structure, the structure of kinship, and alike)" (Mohanty, 2005: 186)? Frances Olsen, for example, states that the discourse of rights cannot resolve social conflicts, that is, that it can only be used to reform them into a certain abstract and finite form - the discourse of rights cannot be successfully separated from politics, morality and other human activities, because right is an integral part of the network of social life (Olsen, 1995: 474-487). Also, as 
we would like to add, since the rise of liberal thought, and, perhaps, even since Plato and Aristotle, our thought has been structured around opposites: rational/ irrational; active/passive, idea/feeling; sense/emotion; culture/nature; power/ sensibility; objective/subjective; abstract/contextual, and principal/personal. Each side of this binary system has its normative and descriptive elements which are ascribed to men and women. In the context of defining and classifying human and women's rights, from different theoretical and social perspectives, dual models occur as the basis of the formation of the identities of men and women (Olsen, 1995: 474).

Certainly, most feminist theorists of law think that human rights, as well as the law, reflect a male stance which is determined by objectivity, distance and abstraction, or, as formulated by Catharine MacKinnon: "Abstract rights will authorise the male experience of the world because the state, in part through law, institutionalises male power. If male power is systemic, it is the regime" (MacKinnon, 1995: 93). Therefore, this would be the field which opens up the possibility of a different perception of the social relations between women and men and their place within the discourse and the practice of rights. The revision of a definitional framework for the category of human rights is the way to discover social reasons and legal principles for the establishment of the rights of women. Taking into consideration the presented findings, we can discuss several conceptual, essential reasons for the introduction of a category of the human rights of women into the corpus of universal human rights and the "obtainment" of a legitimate space within the international law. Those are, primarily, different culturally-shaped gender roles; in other words, the ideology of gender roles; then, the view that discrimination against women is structural; as well as, the social fact which indicates that the forms and consequences of discrimination are extremely gender-based and different in relation to women. Also, the existing legal norms regarding human rights do not express female needs and female experiences; the existence of various social records which show the way in which men and women exercise their rights to an extent which is available to each of them, that is, to a different extent; and, finally, the listed reasons show that there are visible indicators of interdependence between the structural and the institutional discriminations against women.

The advancement of human rights in contemporary democracies is a widely accepted aim, which, by itself, gives a focused and useful framework for searching the ways in which to remove all kinds of discriminations, as well as gender-based discrimination. "The problem to which we should turn is how to regard the universality of human rights in relation to the differences and antagonisms which intersect society. One of such differences is the gender difference" (Salecl, 1996: 23). In this sense, the process of the conceptualisation of the rights of women 
requires that specific experiences of women have to be added to "traditional approaches to human rights in order to make women more visible and in order to transform the notion and the practice of human rights into our culture in such a way as to take into consideration the lives of women more properly" (Bunch, 1995-1996: 174).

\section{Concluding remarks}

Violations of gender-based rights have been significantly neglected and, today, this area of research represents the greatest challenge within the field of human rights. That is why it is useful to further revise the concept of human rights through the process of defining the rights of women as human rights, taking into consideration the "leitmotif" that most women are exposed to different kinds of threats and restrictions of rights. Namely, there is a significant number of social barriers (cultural, economic, political, legal, etc.) which lead to: the feminisation of poverty or to the information that women are poorer than men; that women are more exposed to sexual and physical abuse than men; that women are paid less than men; that women are more dedicated to the care, nurture and tendance of children, more than men; that they sacrifice their professional career for the sake of the family more than men; that, in comparison to their male colleagues, they have fewer opportunities and not enough public and private support in using their abilities within the scientific, academic or other professional careers; that women are, more than men, exposed to and burdened with the imposed stereotypes about their own female roles, (the only) acceptable female behaviour and femininity, and the rest.

The approach to the rights of women is still under the influence of the traditional perception of the entire society - what is right for women and what is not. »It is greatly wrong that women have been neglected in their search for freedom, equality, and for those, all too precisely named 'the rights of men'" (Phillips, 2001: 12). Unfortunately, a paradigmatic attitude towards women's rights is that, as the constancy in the perception of women's rights within legal theory and practice, human rights are still regarded as more important than the rights of women. ${ }^{8}$ It is certain that the curriculum of human rights has to move outside its male-defined norms, in order to make a global response to discrimination against women. This implies the questioning of patriarchal prejudices and the

8 Within the United Nations, the Human Rights Council (previously, the Commission on Human Rights) is better in hearing and investigating the related cases than the Commission on the Status of Women. It has more staff, larger budget and better mechanisms for the implementation of its findings. Therefore, there is a significant difference in view of what can be done if a certain case is considered a violation of women's rights and not a violation of human rights. (See in detail: Bunch, 1996: 178). 
acknowledgement of the rights of women as human rights. ${ }^{9}$ However, from the view of "public values", rationality and democratic development, it is also important to ask the question - whether an increase in social reflexivity, within the context of the general course of the modernisation of society, as a condition in which we have to constantly question the situations in our life, will change the social position of women and force the state to institutionally control discrimination against women in all segments of the society.

\section{References}

Badinter, E. (1986). Jedno je drugo. Sarajevo: Svjetlost

Baines, B., Rubio-Marin, R. ed. (2005). The Gender of Constitutional Jurisprudence. New York: Cambridge University Press

Banč, Š. (1995-1996). Prava žena kao ljudska prava: prilog re-viziji ljudskih prava. U: Politike ljudskih prava. Beogradski krug. 3-4/1-2. 173-184

Blagojević, M. (1991). Žene izvan kruga. Beograd: Institut za sociološka istraživanja Filozofskog fakulteta u Beogradu

Blagojević, M. (2000). Diskriminacija: neplaćeno, potplaćeno i potcenjeno. U: Blagojević, M. (pr.) Mapiranje mizoginije u Srbiji: diskursi i prakse. (475-482). Beograd: Asocijacija za žensku inicijativu

Blagojević, M. (2002). Mizoginija: Kontekstualna i/ili univerzalna. U: Polni stereotipi. Nova srpska politička misao. Posebno izdanje. 21-38

Burdije, P. (2001). Vladavina muškaraca.Podgorica: CID

Bovoar, S. (1982). Drugi pol I-II. Beograd: BIGZ

Giddens, A. (1989). Sociology.Cambridge: Polity Press

Gender Equality - Striving for Justice in an Unequal World. (2005). United Nations Research Institute for Social Development

Levinas, E. (1995-1996). Ljudska prava i dobra volja. U: Politike ljudskih prava. Beogradski krug. 3-4/1-2. 30-32

MacKinnon, C. (1995). Feminizm, Marxism, and the State: Toward Feminist Jurisprudence. In Olsen E. F. (ed.), Feminist Legal Theory I: Foundations and Outlooks. (90 - 104), New York: New York University Press

Mohanti, Č. (2005). Pod pogledom zapada: feminističko učenje i kolonijalni diskursi. Treći program. 161-191

9 Among other things, it is necessary to insist on the term 'the human rights of women' within the academic circles, and public and political institutions; therefore, our opinion is that the human rights of women are a legal category, and, in order to protect those rights, this terminology also has to be introduced into legally binding documents. 
Morgan, L. A. (1998). Glass ceiling effect or cohort effect? A longitudinal study of the gender earnings gap for engineers, 1982 to 1989. American Sociological Review. 479-493

European Women Lobby. Report. Winter, 2013. Dostupno na: http://www.womenlobby.org/publications/reports/?lang=en

Facio, A. Sandova, R. Morgan. M., (2005). Gender Equality and International Human Rights in Costa Rican Constitutional Jurisprudence. In Baines, B., RubioMarin, R. (ed.), The Gender of Constitutional Jurisprudence. (105-120). New York: Cambridge University Press

Olsen, F. E. (1995). Feminism and Critical Legal Theory: An American Perspective. In Olsen, E. F. (ed.), Feminist Legal Theory I: Foundations and Outlooks. (474 - 487). New York: New York University Press

Olsen, E. F. Ed. (1995). Feminist Legal Theory I: Foundations and Outlooks. New York: New York University Press

Pateman, C. (1998). Ženski nered. Zagreb: Ženska infoteka

Pincus, F. L. (2000). Discrimination Comes in Many Forms: Individual, Institutional and Structural. In Adams, M., Blumenfeld, W., Castaneda, R. (ed.), Readings for Diversity and Social Justice. (31-35). New York: Routledge

Phillips, A. (2001). Rađanje Demokracije. Zagreb: Ženska infoteka

Rosener, J. B. (1997). Leadership and the Paradox of Gender. In Walsh, R. M. (ed.), Women, Man and Gender - Ongoing Debates. (294-297). New Haven: Yale University Press

Rorti, R. (1995-1996). Ljudska prava, racionalnost i sentimentalnost. U: Politike ljudskih prava. Beogradski krug. 3-4/1-2. 29-49

Rols, Dž. (1995-1996). Zakon naroda. U: Politike ljudskih prava. Beogradski krug. 3-4/1-2. 9-29

Salecl, R. (1996). Žene kao simptom prava. Ženske Studije. 4. 17-43

Turner, B. S. (ed.). (2006). The Cambridge Dictionary of Sociology. Cambridge University Press

Walsh, R. M. (ed.). (1997). Women, Man and Gender - Ongoing Debates. New Haven: Yale University Press

Young, M. I. (1990). Five Faces of Oppression. In Justice and politics of difference. (39-63). Princeton, New York: Princeton University Press.

Young, M. I. (2004). Polity and Group Difference: A Critique of the Ideal of Universal Citizenship. In Phillips, A. (ed.), Feminism and Politics. (401-429). New York: Oxford University Press 
Мр Наталија Жунић

Асистент Правног факултета,

Универзитет у Нишу

\section{Дискриминација жена и људска права жена}

\section{Резиме}

У раду смо анализирали како и на који начин су повезани концепт људских права жена и феномен и инстанце дискриминације жена. „Мапирање дискриминације жена“ у различитим просторима друштва учинило је видљивим оквире у којима се одвија дискриминација жена, као социјалне групе која има различит друштвени положај у многим аспектима живота друштвене заједнице. Историјска природа женских права и статус жена у модерном друштву показују како је контекст женских права детерминисан феноменом дискриминације жена. Дакле, разговор о концептуализацији појма женских права фокусирали смо, како на сам појам дискриминације жена и начине њеног испољавања, тако и на механизме одржавања система дискриминације жена. Препознавање укупног контекста дискриминације жена отвара и суштинско питање превазилажења дискриминације као важног политичког питања. Дискриминација жена, њена друштвена видљивост и борба против ње која се одвијала унутар идеје о правима и равноправности жена, извор су многих теоријских дебата. Академске расправе и снажан утицај женског покрета довели су до заснивања и остваривања људских права жена на различитим нивоима јавне и приватне сфере друштва, као недељивог дела универзалног режима људских права. Кршења права која су повезана са родом била су значајно занемаривана и утолико сматрамо да је целисходна даља ре-визија концепта људских права, кроз процес дефинисања права жена као људских права, имајући у виду „лајтмотив чињеницу“ да је већина жена изложена различитим врстама угрожавања и онемогућавања права.

Кључне речи: род, дискриминација жена, људска права жена, људска права. 